\title{
Motivation and Learning English: A Study on Nepalese Public High School Learners
}

Suman Laudari

\begin{abstract}
Motivation is long found to be an important factor to affect the task of learning an L2 as it provides the stimulus required to initiate and sustain the task of learning the L2. It is even argued that if learners are motivated, they are likely to succeed in the task of language learning regardless of other factors. The present study examined the Nepalese public high school learners' motivation to learn English. Based on Dörnyei's $(2005 ; 2009)$ second language (L2) motivational Self System as the theoretical framework, this study employed a 64 item questionnaire to collect the data. Correlation and regression were carried out to establish that the main factors affecting learners' English language learning motivation were attitude to learning English and ideal L2 self. However, ought-to L2 self did not contribute to learners' motivation directly, which is on the contrary to the findings of the study done in Asian contexts previously.
\end{abstract}

Key Words: Motivation, L2 Motivational Self System, Ideal L2 Self, Ought to L2 Self

\section{Introduction}

Language learning is a lengthy and tedious process so its success is determined by various factors such as learners' fervour, commitment and perseverance. Actually, in many cases, learners with a higher level of motivation are likely to gain at least some level of knowledge of the language, regardless of other factors, such as aptitude, and working memory. On the other hand, if learners lack motivation, they are not likely to persist on the task of learning the language. This is because motivation is said to be the impetus required to begin the task of language learning and the force to sustain it and succeed in it (Dörnyei, 2001). Hence, it has received growing research attention (Ushioda \& Dörnyei, 2012).
However, in the context of Nepal where English is taught as a foreign language, no independent research on English language learning motivation has been carried out following the Motivational Self System. To this end, the present research was carried out with the aim of exploring the factors behind learning of English as a second language because there is an incessant demand of quality English language teaching in Nepal.

\section{Literature review}

\section{From integrativeness to Self-System}

Up until 1990s, until the evolution of cognitive situated period, the seminal studies of Gardner and his associates had outshined 
the field of motivational research. Since the late 1950s (e.g. Gardner \& Lambert, 1959), the concept of integrative motivation, which is said to have assumed the desire to interact and assimilate with the target language speakers, learners' attitudinal disposition towards language learning situation, and instrumental motivation, which together affect the process of language learning and achievement (Gardner, 1985), was considered to be an important concept. This is because, it was argued to be an important cause of variability in the L2 achievement as learning a second language is different from learning any other subjects (Dörnyei, 2005; Ushioda \& Dörnyei, 2012).

However, it was heavily criticized citing that it was not truly fit for education contexts (Ushioda \& Donryei, 2012); it could not integrate the developments seen in the field of mainstream motivation, and it was unable to fully explain the changes observed in the field of social identity. Hence, there was a need for re-conceptualization in the field of motivation. In response to this need, researchers followed cognitive line of enquiry to explain second language learning motivation.

\section{Cognitive and process oriented approach}

Cognitivemethod was different from earlier approaches in that it analysed the L2 motivation using a theoretical framework that integrated cognitive factors from the mainstream motivational psychology and situated contextual variables that affected motivation (Dörnyei, 2005) yet without completely rejecting the ideas of Gardner and his associates altogether (Ushioda \&Dörnyei, 2012). In line with the cognitive model of enquiry, a large number of studies examined the impact of contextual factors on L2 motivation (e.g. Dörnyei, 1994; Nikolov, 2001). Nonetheless, those studies failed to explain the temporal nature of motivation as their focus was on the situated motivation in relation to language learning success (Ushioda \& Dörnyei, 2012).

Hence, researchers worked towards a model that would explain the fluid nature of motivation during the long and tedious process of the language learning (Dörnyei, 2001, p. 18-45). Thus, next to emerge was the 'Process Oriented Approach which considered L2 motivation at different points of time of language learning (Dörnyei, 2001). This model looked promising in that it recognized the fluid and manifold motivational behaviours that influence language learning in instructional settings (Dörnyei, 2002). Further, it categorized L2 motivation along distinct stages in a temporal axis (Dörnyei\& Otto, 1998; Dörnyei, 2002). The most exhaustive theoretical model of this approach was developed in 1998 by Dörnyei and Otto. Since then, its tenets have been explicitly researched in different contexts (Gardner, Masgoret, Tennant, \& Mihic, 2004; Williams, Burden, \& Lanvers, 2002). However, the model failed to recognize that the different stages cannot be defined clearly (Dörnyei, 2002). Also, the model could not tap into the complexities of L2 learning (Dörnyei, 2009), and failed to consider other contextual factors, such as the status of English as a world language, English regarded to be a must have skill (Graddol, 2006), and use of English in the cyberspace and equal status of its users that influence motivation (Dörnyei, 2005).

\section{The L2 motivational self-system}

Hence, Dörnyei (2005) proposed the theoretical concept of "The L2 motivational self-system", which was found to be useful in explaining the factors that were overlooked and also the new concepts in integrativeness and international posture proposed by Yashima (2002) and other scholars (Yashima, Lori \& Shimizu, 2004). Studies conducted in 
Indonesia (Lamb, 2004) and Japan (Yashima, 2000) established that one of the reasons that learners studied English was not because they had the desire for identification with the foreign community, but they had a strong international posture, i.e. learning second language because of interests in international affairs, foreign culture and maintaining friendship with the people from other communities. This was a unique finding because it expanded the process of identification from a specific community to a global community of English language users.

On the other hand, there were scholars who argued that the process of identification is rather internal because no sooner learners start the task of learning English, they become a de facto member of the global community of English language users (Ushioda, 2006, Lamb, 2012), hence, making it the 'future English-using version' of the self (Dörnyei, 2005).

Furthermore, the study by Lamb (2004) concluded that instrumentality, the faceless pragmatic values of learning a language, was difficult to distinguish from integrativeness because, as he argued: "meeting with westerners, using pop-songs, studying and travelling abroad, pursuing a desirable career - all these aspirations are associated with each other"(p.15). Kormos and Csizér (2008), regarding this, contend that the pragmatic benefits of knowing English and attitudinal disposition towards the international community are interlinked as a consequence of English becoming the world language, which was also evident in the results of the large scale longitudinal survey by Dörnyei and Clément (2001), Dörnyei and Csizér (2002), and Csizérand Dörnyei (2005). Their data of Hungarian school level learners' disposition towards learning foreign languages indicated that the integrativeness, with instrumentality as one of its immediate antecedents, mediated the effects of all the variables on two criterion measure, language choice and intended effort to learn an L2 (Dörnyei, 2009, p. 26-27).

Hence, Dörnyei (2005), in line with Ushioda (2001) and Noels' (2001) findings, postulated that the integrativeness might be better understood as an internal process of identification rather than the identification with an external group. He further averred that this kind of internal identification process also subsumes the internalized instrumental motive of learning the L2, which led to the formulation of 'the L2 Motivational Self System"' (see, Dörnyei, 2005, p. 93-106). Scholars argue that this theory has broadened its frame of reference with the increased capacity for explanatory power without any contradiction with the traditional notion of the L2 motivation (Lamb 2012). So, it is capable of exploring the complexities associated with motivation as it explains the commonalities across cultures yet it is sensitive enough to allow a researcher to discuss the idiosyncrasies of the local context (Ryan 2009).

The L2 Motivational Self System is comprehensive in that it is built upon the concepts of 'possible selves' of Markus and Nurius (1986) and 'self-discrepancy theory' of Higgins (1987; 1998), and also synthesizes Noels' (2001) and Ushioda's (2001) findings on motivation, and it subsumes three constructs: 'the Ideal L2 Self', 'the Ought-to L2 Self' and 'L2 learning experience' (Dörnyei, 2005).

\section{The Ideal L2 Self}

The ideal L2 self houses hopes, aspiration (Islam, Lamb \& Chambers, 2013) and the vision of the self that uses the second language (Kormos \& Csizér, 2008). It also holds the desire to reduce the discrepancy between the learners' actual and ideal selves, in the process of which L2 learners are thought to be motivated to learn the new language or develop the current L2 
competence level (Dörnyei, 2005; Lamb, 2012). This construct is found to be the strongest component of L2 Motivational Self System in many recent studies. Csizérand Kormos (2009), Islam et al. (2013), and Papi (2010) concluded that the learner's motivated behaviour was explained by this variable the most. Similarly, studies by Taguchi, Magid, and Papi (2009) and Ryan (2009) found this variable to correlate significantly with integrativeness.

\section{The Ought-to L2 self}

Ought-to self refers to the attributes that learners believe they ought to possess to avoid the possible negative outcomes (Dörnyei, 2005). Thisconstruct corresponds with the extrinsic motivation of Noels (2001). But, as this construct represents the externally foisted self-image (Ushioda, 2010), it may be less efficient in comparison to the Ideal L2 Self (Kormos, Kiddle\&Csizér , 2011). Hence, it may not have long term significance in maintaining the motivated L2 behaviours.

Taguchi et al. (2009) found that this dimension correlated more closely with the instrumental motives that were associated with preventing unwanted consequences potential to obstruct the L2 related goals. However, Dörnyei, Csizérand Nemeth (2006) did not find a prominent ought-to self dimension in the L2 motivation of Hungarian school pupils nor did Kormos and Csizér (2008) with older learners in the same context. So, Kormos and Csizér (2008) argue that the Ought-to L2 Self might be more relevant in Asian cultures where learners' behaviour is likely to be shaped by parents and other significant ones.

However, the research studies so far conducted in the Asian context do not offer a solid confirmation to the proposition of Kormos and Csizér (2008). For example, the study by Taguchi et al., (2009) which was conducted in three different Asian contexts,
Japan, Iran and China, found that the Oughtto L2 Self contributed less to the criterion measure of intended learning effort. Similarly, Lamb (2012) reports that his study, like previous studies by Csizérand Lukacs (2010), and Kormos and Csizér (2008), failed to identify clear Ought-to Self among Indonesian students which, he argues, might be because of the shortcomings in the construct or in the methods of elicitation.

\section{The L2 learning experience}

The L2 learning experience, the third dimension of the L2 Motivational Self System, is concerned with the ongoing situated processes shaping day to day motivation during the course of language learning (Ushioda, 2011). It, as Dörnyei (2009) argues, 'concerns situated, executive motives related to the immediate learning environment and experience' (p.29). L2 learning experience is significant as it results from the interaction between prior experiences and the present L2 learning environment (Macintyre, Mackinnon \& Clement, 2009).

The research on the L2 Motivational Self System confirms that this construct affects the L2 motivation, roughly as much as the Ideal L2 Self. However, it is also reported to be context specific (Lamb, 2012). It was found to have a strong effect in the Hungarian secondary school context (Csizér \& Kormos, 2009) and Indonesian school context (Lamb, 2012), but not in a Chinese context (Taguchi et al., 2009; Chen, Warden \& Chang, 2005). Nevertheless, Yang and Kim (2011), in their study, with students from four different countries, reported that the contextual factors motivated students from China and Sweden, but not from Japan and Korea. 


\section{Intended learning effort as the criterion measure}

Motivation is related with language learning success indirectly because it is the antecedent of motivated behaviour not the language learning achievement (Papi, 2010). Hence, many of the recent motivational research (Taguchi et al. 2009; Ryan, 2009; Papi, 2010), have used learning effort variable as the criterion measure, and established that it examined motivation and correlated well with all the dimensions of the L2 Motivational Self System. So, this study also uses the 'intended learning effort' as its criterion measure to examine the motivated behaviour of the sample learners in Nepal.

\section{Research questions}

Based on the literature reviewed above, this research aims to answer the following research questions.

1. What motivates Nepalese High School learners to learn English? How useful is the L2 Motivational Self System as a means of understanding and explaining the L2 motivation of Nepalese high school learners?

a. What is the relationship between the three main components of the L2 motivational self-system with each other and with these learners' reported intended efforts to learn English?

2. What other factors are significant in explaining the motivational pattern of these learners?

\section{Method}

\section{Participants}

The sample participants are students of 12 to 20 years of age, with the mean age of 14.99, studying in grade 8 to 10 in 10 different government-funded and privately- funded high schools in three districts, Kathmandu, Lalitpur and Bhaktapur of Nepal. The total number of participants comprises of 609 boys and 648 girls. All of these students have been studying English from the $1^{\text {st }}$ grade as one of their compulsory subjects. They received 3.5 to 4 hours of formal English instruction every week. The detail breakdown of the participant is given below in the table 1 . These participants were chosen in the belief that they would perfectly represent the population as the learners come from public schools set in a rural area of the valley and also from well facilitated private schools.

\section{Table 1}

Breakdown of the participants

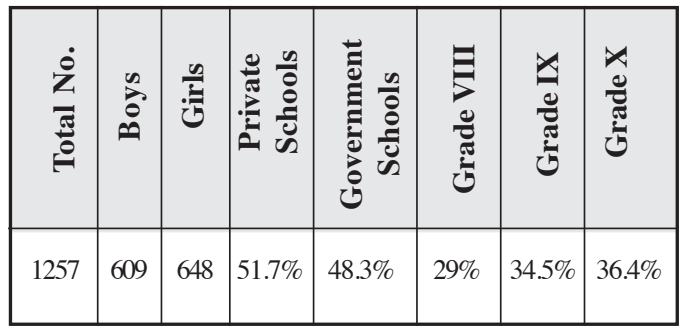

\section{Instruments}

The data were collected using a questionnaire. It consisted of two different sections (see, Appendix-1). The first section consisted of 64 Likert type, ranging across 12 motivational variables covering a broad range of theoretical issues. 9 of 64 items were questions with 5 points, very much (5) to not at all (1), and the rest were statements with 6 points, strongly agree (6) to strongly disagree (1). Appendix-2 gives the details on the scales. Because the theoretical framework of this study is informed by the constructs of the L2 Motivational Self System (Dörnyei, 2005; 2009), the questionnaire was adapted from two recent studies on the L2 Motivational Self System, Ryan (2009), and Islam et al. (2013) 


\section{Procedure}

As this research was carried out as an extension of my research at MATESOL at Lancaster University, I used the same tool which I had used for my previous research because the tool was found to work well in the Nepalese context. For the process of the data collection, the researcher visited the schools located in the rural locations of Kathmandu Valley between October 1, 2013 to January 5, 2013, talked to the principals, students and English language teachers. After gaining the consent of parents, students and principals, I collected the data during their English periods.

The data obtained from the questionnaire was submitted to SPSS (version 20.0) program. After the total for each scale was computed, reliability analyses, and the distribution of the scores were calculated. This indicated the motivational level of sample learners with respect to each scale of the questionnaire. Following this, correlation and regression analyses were done, which provided hints about the interrelationships between variables, and variables with the criterion measure.

\section{Findings of the study}

\section{Reliability analysis}

To find out the internal consistency of the individual items and scales, the reliability scores were computed (see Annex 3). The reliability analysis of the questionnaire showed that its Cronbach's alpha value was 0.87, which is well above the recommended range, $\alpha-0.7$ (Pallant, 2010). The analyses of the individual scales indicated that only two scales scored less than 0.6. But, as the brevity of a scale influences its reliability coefficients
(Pallant, 2010), the scales might have had low a Cronbach value so the two scales scoring below 0.6 were retained for further analysis. However, the scale 'Integrativeness' was dropped from further analyses as its reliability score and the mean inter-item correlation were not acceptable.

\section{Descriptive Statistics}

The descriptive statistics were calculated to inspect how the motivational scales scored, and to examine if there existed any significant variation within the mean score of any scale (Table 2). The results indicated that all scales had a fairly high mean value. While 'Promotion' 'Attitudes to Learning English' scored high, 'English Anxiety' and 'Attitude towards L2 Community' had the lowest mean value among all. Furthermore, the standard deviation value of all the scales was low, which suggested that the sample population was homogenous in nature.

\section{Table 2}

Distribution of the Scores

\begin{tabular}{|l|c|c|c|c|}
\hline \multicolumn{1}{|c|}{ Scale } & N of Items & Mean & Median & $\begin{array}{c}\text { Std. } \\
\text { Deviation }\end{array}$ \\
\hline Instrumentality (Promotion) & 6 & 5.39 & 5.50 & .537 \\
Attitudes to Learning English & 3 & 5.17 & 5.55 & .71 \\
Intended Learning Effort & 6 & 5.11 & 5.16 & .71 \\
Instrumentality (Prevention) & 5 & 5.11 & 5.19 & .59 \\
IdealL2 Self & 8 & 4.97 & 5.00 & .64 \\
International Posture & 8 & 4.94 & 5.00 & .61 \\
Milieu & 5 & 4.87 & 5.00 & .64 \\
Ought-to Lw Self & 5 & 4.70 & 4.83 & .81 \\
English Anxiety & 4 & 4.40 & 4.50 & .93 \\
Attitudes towards L2 community & 4 & 3.82 & 4.00 & .73 \\
\hline
\end{tabular}

\section{Interrelationship among scales}

A correlational analysis was conducted (see Table 3) to ascertain the interrelationships 
among the variables used in this study. The analysis provided a hint about how different motivational factors influenced the overall motivation of the sample learners. From the result, it is evident that the highest correlation was between prevention and the Ought-to L2 Self. Likewise, the Ideal L2 Self had a fairly strong linear relation with the criterion measure and international posture. Also, the results showed that attitude towards learning English had a good correlation with milieu and criterion measure.

Conversely, it can be seen that the correlation of Ought-to L2 Self with the criterion measure is quite low. Similarly, English anxiety did not have a very good linear relation with other factors, including the criterion measure.

\section{Table 3}

Correlation Analysis of the Scales

\begin{tabular}{llllllllllll}
\hline & 1 & 2 & 3 & 4 & 5 & 6 & 7 & 8 & 9 & 10 & 11 \\
\hline Promotion & 1 & & & & & & & & & &
\end{tabular}

Prevention $\quad .459^{* * 1} 1$

International Posture $\quad .494^{* *} .271^{* *} 1$

English Anxiety $\quad .201^{* *} .314^{* *} .198^{* *} 1$

Attitude to Learning English $.444^{* *} .343^{* *} .439^{* *} .148^{* *} 1$

Milieu $\quad .452^{* *} .408^{* *} \cdot 476^{* *} \cdot 243^{* *} \cdot 528^{* *} 1$

Ideal L2 Self $\quad .573^{* *} .371^{* *} .628^{* *} .209^{* *} .498^{* *} .517^{* *} 1$

Ought-to L2 Self $\quad .469^{* *} .674^{* *} .349^{* *} .322^{* *} .385^{* *} .522^{* *} .425^{* *} 1$

Learning Effort $\quad .532^{* *} .349^{* *} .579^{* *} .180^{* *} .598^{* *} .560^{* *} .632^{* *} .396^{* *} 1$

Cultural Interest $\quad .331^{* *} \cdot 128^{* *} \cdot 463^{* *} \cdot 101^{* *} \cdot 272^{* *} \cdot 247^{* *} \cdot 388^{* *} \cdot 202^{* *} \cdot 429^{* *} 1$

Attitude to L2 Community $.409^{* *} .200^{* *} .457^{* *} .152^{* *} .377^{* *} .340^{* *} .444^{* *} .271^{* *} .475^{* *} .581^{* *} 1$

**. Correlation is significant at the 0.01 level (2-tailed).

\section{Regression analyses}

Stepwise multiple regression analyses were done to find out which motivational scales contributed most to the criterion measure and to examinethe factors that contributed towards the basic constructs of the L2 Motivational Self-System. Table 4 and 5 summarize these results. Prior to conducting multiple regressions, it was confirmed that the assumption of normality, linearity, multicollinearity, and homogeneity were not violated.

The $R^{2}$ value for the model based on intended learning effort as the criterion measure is 0.58 , meaning that the model explains 58 percentage of the variance in the reported learning efforts of the participants. This value is considered reasonably high as per the standards of the research in L2 motivation (Dörnyei, 2009).

\section{Table 4}

Regression Model Based on Intended Learning Efforts as the Criterion Measure* $\mathrm{p}<0.0001$

\begin{tabular}{|llll|}
\hline Final Model & & & \\
\hline Scales & $B$ & SE $B$ & $\hat{a}$ \\
Attitude to Learning English & .211 & .021 & .250 \\
Ideal L2 Self & .200 & .026 & .216 \\
International Posture & .123 & .026 & .128. \\
Milieu & .134 & .021 & .162 \\
Cultural Interest & .090 & .021 & .105 \\
Promotion & .109 & .028 & .098 \\
Attitude towards L2 Community & .058 & .021 & .070 \\
$R^{2}$ & 0.581 & & \\
\hline F for change in R2 & 7.576 & & \\
\hline
\end{tabular}

The model for the criterion measure shows that seven scales have contributed to the prediction of the reported learning effort of the sample learners. Of these seven scales, learners' attitude to learning English and their Ideal-L2 Self have contributed the most.

As mentioned earlier, stepwise regression analyses were also carried out based on the Ideal L2 Self, Ought-to L2 Self, and Attitudes to Learning English as criterion measures to explore the L2 motivation system of the sample learners. The results indicate that the Ideal L2 Self is best explained by international posture, their effort in learning English and promotional instrumentality. Regarding the model for the Ought-to L2 self, prevention and milieu 
are found to explain it the best. Interestingly, promotional instrumentality contributes to the model slightly. The results for the model for attitudes to learning English indicate that learning effort and the milieu contribute it to the best.

\section{Discussion}

The findings of this studylend support to 'L2 Motivational Self System' (Dörnyei, 2005; 2009) as a tool for examining the motivation of the English as a Foreign Language (EFL) learners. The results of the correlation analysis indicate that the three major components of the L2 Motivational Self System are related to each other significantly. Further, the results of the regression indicate that the Ought-to L2 Self and attitude to language learning contribute to the model for the Ideal L2 Self and Ideal L2 Self contributes to the model for the other two components of the L2 motivational self-system. These results suggest that the Ideal L2 Self is an indispensable part of L2 learning motivation and having a well-developed and established imagined selves related to the second language is pivotal in its

\begin{tabular}{|c|c|c|c|}
\hline \multicolumn{4}{|l|}{ Final Model } \\
\hline Scales & $B$ & $\mathrm{SE} B$ & $\beta$ \\
\hline \multicolumn{4}{|c|}{ Criterion Measure 1:Ideal L2 Self } \\
\hline International Posture & .298 & .027 & .286 \\
\hline Learning Effort & .249 & .032 & .230 \\
\hline Promotion & .233 & .031 & .193 \\
\hline Milieu & .073 & .024 & .081 \\
\hline Attitude to Learning English & .054 & .024 & .060 \\
\hline Attitude to L2 Community & .052 & .021 & .058 \\
\hline Ought to L2 Self & .049 & .019 & .062 \\
\hline$R^{2}$ & .560 & & \\
\hline$F$ for change in $R 2$ & 5.26 & & \\
\hline \multicolumn{4}{|c|}{ Criterion Measure 2 :Ought to L2 Self } \\
\hline Prevention & .518 & .025 & .492 \\
\hline Milieu & .264 & .028 & .234 \\
\hline Promotion & .140 & .039 & .092 \\
\hline English Anxiety & .070 & .018 & .081 \\
\hline Ideal L2 Self & .065 & .033 & .052 \\
\hline$R^{2}$ & .545 & & \\
\hline F for change in $R$ square & 3.90 & & \\
\hline \multicolumn{4}{|c|}{ Criterion Measure 3 : Attitude to Learning English } \\
\hline Learning Effort & .397 & .038 & .334 \\
\hline Milieu & .218 & .028 & .221 \\
\hline Promotion & .082 & .040 & .062 \\
\hline Ideal L2 Self & .091 & .035 & .083 \\
\hline Attitude to L2 Community & .067 & .026 & .069 \\
\hline Prevention & .058 & .024 & .063 \\
\hline$R^{2}$ & .432 & & \\
\hline$F$ for change in $R$ square & 5.86 & & \\
\hline
\end{tabular}
long term success (Csizér and Lukacs, 2009; Dörnyei, 2009). And, the future selves that learners imagine of are shaped by their present language learning experience, which shapes the language learning attitude (Lamb, 2012; Papi \& Teimouri, 2012). In addition, Ought-to L2 Self's presence as one of the predictive variable of Ideal L2 Self seem to suggest that, in contrast to the findings of Kormos and Csizér (2008 with Hungarian high school learners) and Kormos et al. (2011 with Chilean high school learners), Nepalese high school learners' Ideal L2 Selves seem to be balanced by the foreseeable negative outcomes that the failure to learn English could bring to them.

Further, these findings also seemto suggest that the components of L2Self system are three different constructs and measure different aspects of L2 motivationthough they are interrelated (Dörnyei, 2010).

\section{Table 5}

Regression model based on the components of the L2 Motivational Self System

Also, the results of the regression analyses show that of the seven variables that have contributed to the model for the criterion measure, Ideal L2Self and attitude to learning English are the top two, which is in consonant with the results of the recent studies conducted in Hungarian context (Kormos \& Csizér, 2008), Indonesian context (Lamp, 2012), Iranian context (Papi \& Teimouri, 2012) and Pakistani context (Islam et. Al, 2013). But it should be noted that Ought-to L2 Self did not explain any variance in the model 
which is in converse to the results of the studies by Islam et al. (2013) in Pakistan, Taguchi et al. (2009) in three different Asian contexts and Papi (2010) in Iranian context. So, the findings of the study does not lend credence to the stance of Kormos et al. (2011) that Ought-to L2 Self might be more influential in the motivation of Asian students.

Though, the contribution of milieu (13\%), a construct closely associated with Oughtto L2 Self, to the model suggests that the role of parents and other family members cannot be undermined, it should be noted that the Ought-to L2 Self seems to be more influential in the societies where socioeducational factors exert pressure on learners to compete with their peers and they are bound to study English to pass the examination. As high school learners studying in public schools in Nepal do not receive such pressure, as the in the context of China, Singapore, Japan or Hong Kong, the Ought-to L2 Self might have been less effective in the present context. Further, it also echoes the fact that externally regulated goals may be less influential in enhancing the motivated behaviour of learners (Kormos et al. 2011).

The variance that the Ideal L2 Self explains in the model for the criterion measure, however, is less than that the summary figure of $40 \%$ of Dörnyei and Ushioda (2011) and findings of many other studies (Kormos \& Csizér , 2008; Csizér , \& Lukacs, 2010; Papi, 2010; Lamb, 2012). Nonetheless, as the learners seem to have enjoyed the present language learning experience, given language learning attitude is the highest contributor to the model, it can probably be argued that this will exert positive effect in the future selves of learners, resulting in the motivated behaviour. This argument becomes more obvious if considered the correlation values of the Ideal L2 Self with the criterion measure, $r-0.63$, which is in line with the findings of Islam et al. (2013), Taguchi et al. (2009) and Ryan (2009). Statistically, as the correlation figure of 0.5 or above is said to have a large effect (Pallant, 2010), it can be argued that the 'Ideal L2 Self' is inevitable component of L2 motivation (Csizér \& Lukacs, 2009) and is the most important determinant factor of L2 motivation.

Though relatively less contribution, the effect of Ideal L2 Self in the motivated behaviour of these learners seem to hint "... [that] intrinsic interest and a strong selfconcept, as embodied by the construct of the ideal L2 self, are more powerful predictors of how much effort students are willing to invest in learning than extrinsic motivational forces" (Csizér \& Kormos, 2009 , p. 106). Also, it seems to suggest that these learners have realized their language learning goals strongly, and thus are motivated to learn English (Kormos et al. 2011). In consequence, this seems to have linked the Ideal L2 Self with the intended effort (Kormos et al. 2011), resulting into motivated behaviour. Eventually, this suggests that "a strong belief and a clear visualization of the self is not only a predictor but a prerequisite for achieving learning goals" (Csizér \& Kormos, 2009, p. 106).

Regarding other factors that are significant in explaining the motivational pattern of these learners, instrumentality (promotion), instrumentality (prevention), international posture, milieu, cultural interest and attitude towards L2 community are seen to have significance. Of all these variables, international posture, milieu, cultural interest, promotion and attitude towards L2 community explain some variance in the model for the criterion measure. And, of these five factors, milieu and international posture explain $13 \%$ and $12 \%$ of the variance in the model and also have a high correlation with the criterion measure. 
These results are in line with the results of the recent studies done in different contexts (Kormos \& Csizer, 2008; Ryan, 2009, Islam et al, 2013).

The presence of international posture as one of the predictive variables of the motivated behaviour of learners suggest, as argued by Kormos et al. (2011), that these learners' interest to communicate in English with the people from other countries, their desire to extend their friendship with them, their interest to know about international community and international affair seem to have motivated them to invest effort in learning English. Also, learners' awareness of importance of English in the globalized world and interest in becoming the member of this global community seemed to have provided the stimuli for learning English (Yashima, 2002; Lamb, 2004).

As for milieu as one of the components of learners' motivated behaviour, it can be argued that learners' family environment is significant in shaping their desired future images (Kormos \& Csizér, 2008), and the effort and time learners invest in L2. This may further hint that the immediate social contacts of high school learners influence their future images as Kormos (2011) argues milieu "shape[s] internalized selfconcept indirectly with the mediation of the Ought-to L2 Self" (p. 509).

Furthermore, the results of the regression and correlation distinctly confirm the fact that promotion and prevention dimensions of instrumentality are related to Ideal L2 Self and Ought-to L2 Self respectively as argued by Dörnyei (2009).

\section{Conclusion}

Fundamentally, this study had two fold objectives; first, to ascertain what motivates Nepalese high school learners to study English so as to compare them with their global counterparts and secondly, to confirm if Doryei's $(2005,2009)$ L2 Motivation Self System is useful in explaining the language learning motivation of EFL learners in a new context. The study concludes, using L2 Motivation Self System as its theoretical framework, that these learners' attitude to learning English, which is shaped by their immediate language learning experience, and their Ideal L2 Selves are major stimuli for learning English. Similarly, several other factors such as milieu, international posture, promotion, cultural interest, attitude towards L2 community were found to have played a role in their motivation. As argued by Yashima $(2000 ; 2002)$ and Lamb (2004) learners' interest in international affairs and desire to become the member of global English speaking community also seem to have influenced L2 learning motivation of learners. The study attempted to explain these phenomena while discussing these statistics.

The study is revealing in that motivation can be an influential tool in teaching English in Nepal. While Nepalese classrooms lack basic things required for effective teaching and learning, teachers can employ motivational strategies to make their teaching effective. Teachers can employ motivational strategies to motivate their students and also have their students think of their future selves (related to learning English) and set those future selves as learning goals in present. This is expected to result in motivated behaviour with high learning achievements.

However, it is worth noting that if the data had been collected from different geographical regions of the country, the patterns of the motivation might have been different. So it is recommended that, should further research be carried out, data be collected from different parts of the country. Likewise, it is also recommended 
that qualitative study be conducted as motivation is a complex system and is multifaceted and qualitative study holds potential to explore those factors.

\section{About the author}

Suman Laudari, a freelance researcher and writer, is the training coordinator to Nepal English Language Teachers' Associations (NELTA). He is also a visiting faculty to Kathmandu University School of Education. His research interests are motivation, writing in second language and task-planning.

\section{References}

Chen, J. F., Warden, C. A., \& Chang, H.-T. (2005). Motivators that do not motivate: The case of Chinese EFL learners and the influence of culture on motivation. TESOL Quarterly, 39(4), 609-633.

Csizér, K., \& Dörnyei, Z. (2005). The internal structure of language learning motivation and its relationship with language choice and learning effort. The Modern Language Journal, 89(1), 19-36.

Csizer, K., \& Kormos, J. (2009). Learning experiences, selves and motivated learning behaviour: A comparative analysis of structural models of Hungarian secondary and university learners of English. In Z. Dörnyei \& E. Ushioda (Eds.), Motivation, language identity and the L2 self (pp. 98-119). Bristol: Multilingual Matters.

Csizer, K., \&Lukacs, G. (2010). The comparative analysis of motivation, attitudes and selves: The case of English and German in Hungary. System 38(1), 1-13.

Dörnyei, Z. (1994). Motivation and motivating in the foreign language classroom. Modern Language Journal, 78(3), 273-284.

Dörnyei, Z. (2001). Teaching and researching motivation. Harlow, UK: Pearson Education Limited.

Dörnyei, Z. (2002). The motivational basis of language learning tasks. In P. Robinson (Ed.), Individual differences and instructed language learning (pp.137-158). Amsterdam: John Benjamins Publishing.

Dörnyei, Z. (2005). The psychology of the language learner: Individual differences in second language acquisition. USA: Lawrence Erlbaum Associates.

Dörnyei, Z. (2009). The L2 Motivational Self System. In Z. Dörnyei \& E. Ushioda (Eds.), Motivation, language identity and the L2 self (pp. 9-42). Bristol: Multilingual Matters.

Dörnyei, Z. (2010). Researching motivation: From integrativeness to the ideal L2 self. In S. Hunston\& D. Oakey (Eds.), Introducing applied linguistics: Concepts and skills (pp. 74-83). London: Routledge.

Dörnyei, Z., \& Clément, R. (2001). Motivational characteristics of learning different target languages: Results of a nationwide survey. In Z. Dörnyei \& R. W. Schmidt (Eds.), Motivation and second language acquisition (pp. 399-432). Honolulu: University of Hawaii Press.

Dörnyei, Z., \& Csizér, K. (2002). Some dynamics of language attitudes and motivation: Results of a longitudinal nationwide survey. Applied Linguistics, 23(4), 421-462.

Dörnyei, Z., Csizér, K., \& Nemeth, N. (2006). Motivation, language attitudes and 
globalization: A Hungarian perspective. Bristol, UK: Multilingual matters.

Dörnyei, Z., \& Otto, I. (1998). Motivation in action: a process model of L2 motivation. In: Working Papers in Applied Linguistics, 4, 43-69.

Dörnyei, Z., \& Ushioda, E. (2011). Teaching and researching motivation ( $2 \mathrm{nd}$ ed.). Harlow: Longman.

Gardner, R.C. (1985). Social psychology and second language learning: the role of attitudes and motivation. London: Edward Arnold Publishers.

Gardner, R.C., \& Lambert, W.E. (1959). Motivational variables in second language acquisition. Canadian Journal of Psychology, 13(4), 266-272.

Gardner, R.C., Masgoret, A.-M., Tennant, J., \&Mihic, L. (2004). Integrative motivation: Changes during a year-long intermediate-level language course. Language Learning, 54(1), 1-34.

Graddol, D. (2006). English next. Why global English may mean the end of 'English as a foreign language'. London: British Council.

Higgins, E.T. (1987). Self-discrepancy: A theory relating self and affect. Psychological Review, 94, 319-340.

Higgins, E.T. (1998). Promotion and prevention: Regulatory focus as a motivational principle. Advances in Experimental Social Psychology, 30,1-46.

Islam, M., Lamb, M., \& Chambers, G. (2013). The L2 motivational self system and national interest: A Pakistani perspective. System, 41(2), 231-244.

Kormos, J., \&Csizer, K. (2008). Age-related differences in the motivation of learning English as a foreign language: Attitudes, selves and motivated learning behavior. Language learning, 58(2), 327-355.

Kormos, J., Kiddle, T., \& Csizer, K. (2011). System of goals, attitudes, and selfrelated beliefs in second-languagelearning motivation. Applied Linguistics, 32(5), 495 - 516.

Lamb, M. (2004). Integrative motivation in a globalizing world. System, 32(1), 319.

Lamb, M. (2012). A self system perspective on young adolescents' motivation to learn English in urban and rural settings. Language Learning, 62(4), 997-1023.

Macintyre, P.D., Mackinnon, S.P., \& Clement, R. (2009). The baby, the bathwater, and the future of language learning motivation research. In Z. Dörnyei \& E. Ushioda (Eds.), Motivation, language identity and the L2 self (pp. 9-42). Bristol, UK: Multilingual Matters.

Markus, H., \&Nurius, P. (1986). Possible selves. American Psychologist, 41, 954969.

Nikolov, M. (2001). A study of unsuccessful language learners. In Z. Dörnyei \& R. Schmidt (Eds.), Motivation and second language acquisition (pp. 147-172). Honolulu: University of Hawaii Press.

Noels, K.A. (2001). Learning Spanish as a second language: Learners' orientations and perceptions of their teachers' communication style. Language Learning, 51(1), 107-144.

Pallant, J. (2010). SPSS survival manual: A step by step guide to data analysis using 
SPSS ( $4^{\text {th }}$ ed). Berkshire, England: Open University Press.

Papi, M. (2010) The L2 motivation self system, L2 anxiety, and motivated behavior: A structural equation modeling approach. System 38(3), 467-479.

Papi, M. \&Teimouri, Y. (2012). Dynamics of selves and motivation: A crosssectional study in the EFL context of Iran. International Journal of Applied Linguistics, 22(3), 287-309.

Ryan, S. (2009). Self and identity in L2 motivation in Japan: the ideal L2 self and Japanese learners of English. In Z. Dörnyei, \& E. Ushioda (Eds.), Motivation, Language Identity and the L2 Self (pp. 120-143). Bristol: Multilingual Matters.

Taguchi, T., Magid, M., \&Papi, M. (2009). The L2 motivational self system among Japanese, Chinese and Iranian learners of English. In Z. Dörnyei \& E. Ushioda (Eds.), Motivation, language identity and the L2 self (pp. 66-97). Bristol: Multilingual Matters.

Ushioda, E. (2001). Language learning at university: Exploring the role of motivational thinking. In Z. Dörnyei, \& R. Schmidt (Eds.), Motivation and second language acquisition (pp. 91-124). Honolulu, Hawaii: University of Hawaii Press.

Ushioda, E. (2006). Language motivation in a reconfigured Europe: Access, identity, autonomy. Journal of Multilingual and Multicultural Development, 27(2), 148161.

Ushioda, E. (2010). Motivating learners to speak as themselves. In G. Murray, X. Gao, \& T. Lamb (Eds.), Identity, motivation and autonomy in language learning (pp. 11-24). Bristol, UK: Multilingual Matters.

Ushioda, E. (2011). Language learning motivation, self and identity: Current theoretical perspectives. Computer Assisted Language Learning, 24(3), 199-210.

Ushioda, E., \& Dörnyei, Z. (2012). Motivation. In S. Gass\& A. Mackey (Eds.), The Routledge handbook of second language acquisition (pp. 396-409). New York: Routledge.

Williams, M., Burden, R., \&Lanvers, U. (2002). French is the language of love and stuff: Student perceptions of issues related to motivation in learning a foreign language. British Educational Research Journal, 28(4), 503-528.

Yang, J. S., \& Kim, T. Y. (2011). The L2 motivational self-system and perceptual learning styles of Chinese, Japanese, Korean and Swedish students. English Teaching, 66(1), 141162.

Yashima, T. (2000). Orientations and motivations in foreign language learning: A study of Japanese college students. JACET Bulletin, 31, 121-134.

Yashima, T. (2002). Willingness to communicate in a second language: The Japanese EFL context. Modern Language Journal, 86, 54-66.

Yashima, T., Lori, Z. N., \& Shimizu, K. (2004). The influence of attitudes and affect on willingness to communicate and second language communication. Language Learning, 54, 119-152.

The author can be reached at laudari.sum@gmail.com if you need data tools, statistical analysis results and the consent letters. 


\section{Appendices}

\section{Appendix 1}

\section{Research Tool}

\section{Motivational factors questionnaire}

The following is the list of statements about English language learning motivation. Read through them and tick one of the options. The value of number is mentioned below. Please be honest while answering the questions.

\begin{tabular}{|c|c|c|c|c|c|c|c|}
\hline No. & Statements & 6 & 5 & 4 & 3 & 2 & 1 \\
\hline 1 & I like English language. & & & & & & \\
\hline 2 & $\begin{array}{l}\text { I think knowing English would help me to become a better educated } \\
\text { person. }\end{array}$ & & & & & & \\
\hline 3 & $\begin{array}{l}\text { I have to leam English because without passing the English subject, I } \\
\text { cannot pass my final examination. }\end{array}$ & & & & & & \\
\hline 4 & $\begin{array}{l}\text { I would like to make friends with those who can speak English, if } \\
\text { possible, from other countries. }\end{array}$ & & & & & & \\
\hline 5 & $\begin{array}{l}\text { I am worried that other speakers of English would find my English } \\
\text { strange (not of very good quality). }\end{array}$ & & & & & & \\
\hline 6 & \begin{tabular}{|l} 
Learning English is great. \\
\end{tabular} & & & & & & \\
\hline 7 & $\begin{array}{l}\text { I am often told by my parents/guardians that English is important for my } \\
\text { future. }\end{array}$ & & & & & & \\
\hline 8 & When I think about my future, I see myself using English. & & & & & & \\
\hline 9 & $\begin{array}{l}\text { I have to study English, because, if I do not study it, I think my parents } \\
\text { and friends will be disappointed with me. }\end{array}$ & & & & & & \\
\hline 10 & It is important for me to learn English. & & & & & & \\
\hline 11 & $\begin{array}{l}\text { I think it is important to learn English in order to learn more about the } \\
\text { culture and art of its speakers. }\end{array}$ & & & & & & \\
\hline 12 & If I have good English, it would help me in getting a better paying job. & & & & & & \\
\hline 13 & $\begin{array}{l}\text { I need to leam English because I do not want to get bad marks in the } \\
\text { university or in other Engl ish language tests like TOEFL/IELTS in the } \\
\text { future. }\end{array}$ & & & & & & \\
\hline 14 & $\begin{array}{l}\text { I am interested to read and watch news about foreign countries or } \\
\text { international events. }\end{array}$ & & & & & & \\
\hline 15 & I get nervous and confused when I am speaking English. & & & & & & \\
\hline 16 & I always wait for my English classes to begin because I enjoy them. & & & & & & \\
\hline 17 & $\begin{array}{l}\text { Studying English is important to me because it makes my family } \\
\text { members happy and gives them satisfaction. }\end{array}$ & & & & & & \\
\hline 18 & $\begin{array}{l}\text { Whenever I think of my future career, I imagine myself being able to use } \\
\text { English in my job. }\end{array}$ & & & & & & \\
\hline 19 & $\begin{array}{l}\text { I consider learning English important because the people I respect think } \\
\text { that I should do it. }\end{array}$ & & & & & & \\
\hline 20 & I am ready to make great efforts to learn English. & & & & & & \\
\hline 21 & $\begin{array}{l}\text { I would like to become simi lar to the people of English-speaking } \\
\text { countries by adopting their culture. }\end{array}$ & & & & & & \\
\hline 22 & $\begin{array}{l}\text { Studying English is important to me because I a m planning to study } \\
\text { abroad. }\end{array}$ & & & & & & \\
\hline 23 & If I do not study English now, I will not become successful in the future. & & & & & & \\
\hline 24 & $\begin{array}{l}\text { I talk about situations and events in foreign countries with my family } \\
\text { and/or friends. }\end{array}$ & & & & & & \\
\hline 25 & $\begin{array}{l}\text { I feel nervous and uneasy if I have to speak to someone in English } \\
\text { language. }\end{array}$ & & & & & & \\
\hline 26 & Learning English is one of the most important aspects in my life. & & & & & & \\
\hline 27 & My friends encourage me to learn English. & & & & & & \\
\hline 28 & $\begin{array}{l}\text { If my drea ms come true, I will use English fluently and accurately in the } \\
\text { future. }\end{array}$ & & & & & & \\
\hline
\end{tabular}




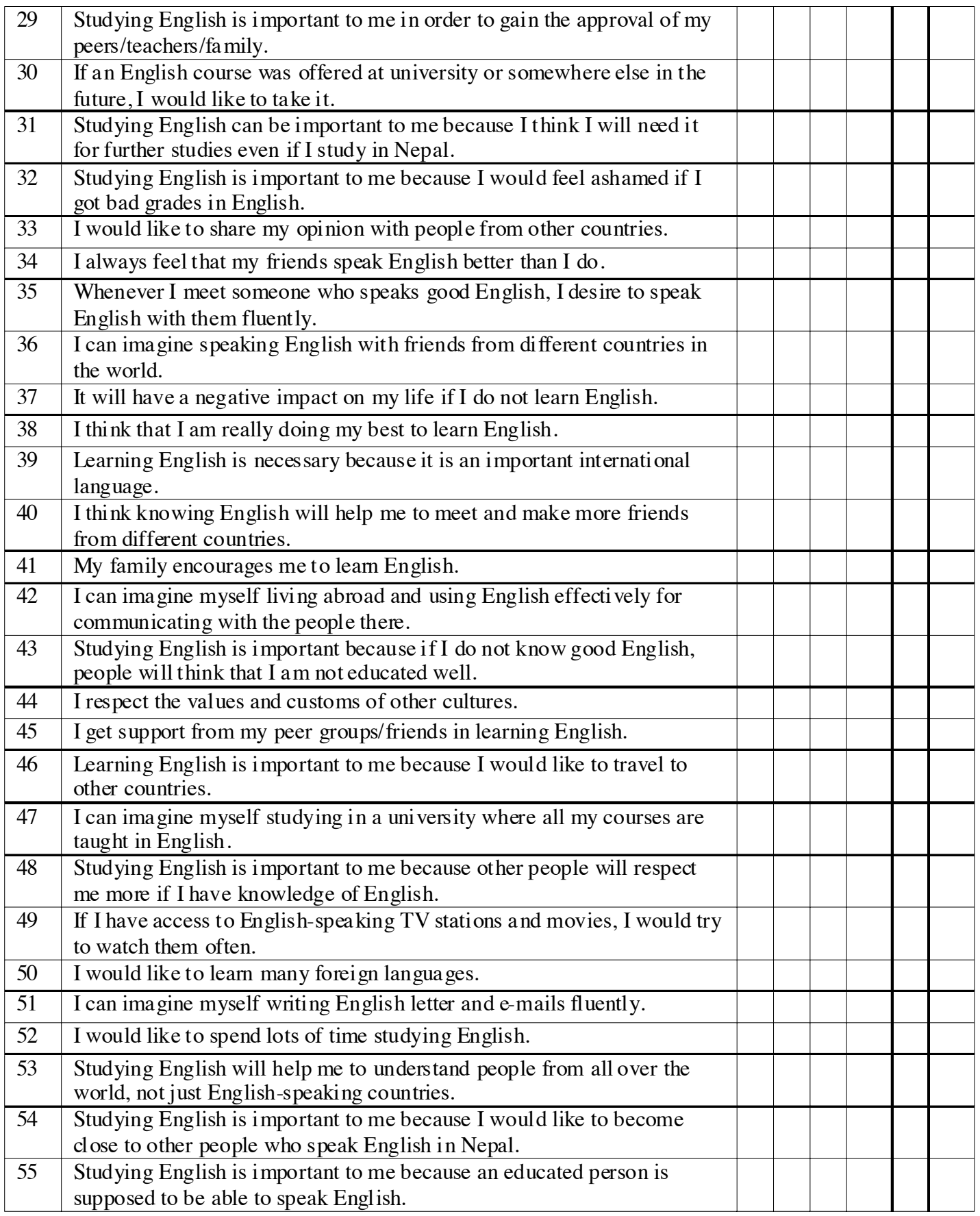
6- Strongly Agree
5- Agree
4- Slightly Agree
3-Slightly Disagree
2- Disagree 1-

Strongly Disagree 


\begin{tabular}{|c|c|c|c|c|c|}
\hline No. & Question & 5 & 4 & 3 & 2 \\
\hline 56 & Do you like the music of English-speaking countries? & & & & \\
\hline 57 & $\begin{array}{l}\text { Do you think that Eng lish speaking countries are the best } \\
\text { countries in the world? }\end{array}$ & & & & \\
\hline 58 & $\begin{array}{l}\text { Do you want to know the culture and art of English-speaking } \\
\text { countries? }\end{array}$ & & & & \\
\hline 59 & $\begin{array}{l}\text { Would you like to know more about people from English- } \\
\text { speaking countries? }\end{array}$ & & & & \\
\hline 60 & $\begin{array}{l}\text { Do you think that Eng lish-speaking countries have an } \\
\text { important role in the world? }\end{array}$ & & & & \\
\hline 61 & Do you like meeting people from English-speaking countries? & & & & \\
\hline 62 & $\begin{array}{l}\text { Do you like TV programmes or movies made in English- } \\
\text { speaking countries? }\end{array}$ & & & & \\
\hline 63 & Would you like to travel to English-speaking countries? & & & & \\
\hline 64 & $\begin{array}{l}\text { Do you like English magazines, new spapers, or books } \\
\text { published in English-speaking countries? }\end{array}$ & & & & \\
\hline
\end{tabular}

5- Very much

\section{1- Not at all}

\section{6-Strongly Agree 5- Agree \\ Agree 3-Slightly Disagree \\ 4-Slightly \\ 2-Disagree 1-Strongly Disagree}

Name (Optional):

Age:

Gender: Male / Female

Class:

School:

\section{Appendix 2}

\section{Motivational factors questionnaire}

Cultural Interest

1. Do you like the music of Englishspeaking countries?

2. Do you like English magazines, newspapers, or books published in English-speaking countries?

3. Do you want to know the culture and art of English-speaking countries?
3- So-So

2 - Not much

4. Do you like TV programmes or movies made in English-speaking countries?

\section{Attitudes towards L2 community}

5. Do you think that English-speaking countries have an important role in the world?

6. Do you like meeting people from English-speaking countries?

7. Would you like to know more about people from English-speaking countries?

8. Would you like to travel to Englishspeaking countries?

9. Do you think that English speaking countries are the best countries in the world?

\section{Integrativeness}

10. I like English.

11. I think it is important to learn English in order to learn more about the culture and art of its speakers. 
12. I would like to become similar to the people of English-speaking countries by adopting their culture.

\section{Instrumentality (Promotion)}

13. I think knowing English would help me to become a better educated person.

14. If I have good English, it would help me in getting a better paying job.

15. Studying English is important to me because I am planning to study abroad.

16. Studying English can be important to me because I think I will need it for further studies even if I study in Nepal.

17. Learning English is necessary because it is an important international language.

18. Learning English is important to me because I would like to travel to other countries.

\section{Instrumentality (Prevention)}

19. I have to learn English because without passing the English subject I cannot pass my final examination.

20. I need to learn English because I do not want to get bad marks in the university or in other English language tests like TOEFL/IELTS in the future.

21. If I do not study English now, I will not become successful in the future.

22. Studying English is important to me, because I would feel ashamed if I got bad grades in English.

23. Studying English is important because I do not know good English people will think that I am not educated well.

\section{International Posture}

24. If possible, I would like to make friends who can speak English from other countries .

25. I am interested to read and watch news about foreign countries or international events.

26. I talk about situations and events in foreign countries with my family and/or friends.

27. I would like to share my opinion with people from other countries.

28. I think knowing English will help me meet and make more friends from different countries.

29. I respect the values and customs of other cultures.

30. I would like to learn many foreign languages.

31. Studying English will help me to understand people from all over the world, not just English-speaking countries.

\section{English Anxiety}

32. I am worried that other speakers of English would find my English strange (not of very good quality).

33. I get nervous and confused when I am speaking English.

34. I feel nervous and uneasy if I had to speak to someone in English language.

35. I always feel that my friends speak English better than I do.

\section{Attitudes to Learning English}

36. Learning English is great.

37. I always wait for my English classes to begin because I enjoy them.

38. Learning English is one of the most important aspects in my life. 


\section{Milieu}

39. I am often told by my parents / guardian that English is important for my future.

40. Studying English is important to me because it makes my family members happy and gives them satisfaction.

41. My friends encourage me to learn English.

42. Whenever I meet a fluent someone who speaks good English, I desire to speak English with them fluently.

43. My family encourages me to learn English.

44. I get support from my peer group/ friends in learning English.

\section{Ideal L2 self}

45. When I think about my future, I see myself using English.

46. Whenever I think of my future career, I imagine myself being able to use English in my job.

47. If my dreams come true, I will use English fluently and accurately in the future.

48. I can imagine speaking English with friends from different countries in the world.

49. I can imagine myself living abroad and using English effectively for communicating with the people there.

50. I can imagine myself studying in a university where all my courses are taught in English.

51. I can imagine myself writing English letter and e-mails fluently.

52. Studying English is important to me because I would like to become close to other people who speak English in Nepal.

\section{Ought-to L2 self}

53. I have to study English, because, if I do not study it, I think my parents or friends will be disappointed with me.

54. I consider learning English important because the people I respect think that I should do it.

55. Studying English is important to me in order to gain the approval of my peers / teachers/family.

56. It will have a negative impact on my life if I do not learn English.

57. Studying English is important to me because other people will respect me more if I have knowledge of English.

58. Studying English is important to me because an educated person is supposed to be able to speak English.

\section{Intended Learning Effort}

59. It is important for me to learn English.

60. I am ready to make great efforts to learn English.

61. If an English course was offered at university or somewhere else in the future, I would like to take it.

62. I think that I am really doing my best to learn English.

63. If I have access to English-speaking TV stations and movies, I would try to watch them often.

64. I would like to spend lots of time studying English. 